\title{
Taxonomy of the fishes of the family Leiognathidae (Pisces, Teleostei) from the West coast of India
}

\author{
K. J. ABRAHAM ${ }^{1}$, K. K. JOSHI ${ }^{2,3} \&$ V. S. R. MURTY ${ }^{2}$ \\ ${ }^{1}$ Department of Zoology and Aquaculture, St Xavier's College, Vaikom, Kerala, India \\ ${ }^{2}$ Central Marine Fisheries Research Institute, P.B.No.1603, Kochi-682 018, India \\ ${ }^{3}$ Corresponding author.E-mail: joshycmfri@ rediffmail.com
}

\begin{abstract}
A total of 16 species of the family Leiognathidae have been collected from the commercial landings from Cochin and Neendakara on the western coast of India from 1998-2000. Detailed morphometric data have been collected and all 16 species are redescribed with live color photographs here. Various relationships in the morphometric characteristics have been studied and regression equations fitted to enable comparison of the populations of these species from Kerala with those from other regions. Of the 16 species collected and described in the present work, five species, Nuchequula nuchalis, Equulites absconditus, Equulites leuciscus, Aurigequula longispina, and Gazza achlamys, are reported for the first time from the entire western coast of India.
\end{abstract}

Key words: slipmouths, silverbellies, ponyfishes, Leiognathus, West coast

\section{Introduction}

Fisheries are one of the most important renewable resources. With increasing fishing pressure, the only option left for the sustainability of fisheries is their rational management. Proper management is possible with a thorough knowledge of the dynamics of the fish stocks. For a meaningful study of the dynamics, knowledge of natural history of the species is necessary and this in turn can be acquired by the correct identification of fish species. This assumes greater importance in tropical seas where, a multitude of closely related and morphologically similar species occur. The role of taxonomy and proper identification cannot be overstressed in studies of population dynamics. The study is also a step towards understanding the bewildering biodiversity that characterizes the tropical seas.

In regard to the taxonomy of the family Leiognathidae from the Indian waters, Day (1878), described 14 species. Munro (1955) described twelve species of ponyfish (as members of this family are often called, they are also called silverbellies and slipmouths) from neighboring Sri Lanka. Recently Chakrabarty et al. (2008) redescribed the ponyfishes of Sri Lanka and resurrected Aurigequula Fowler, 1918. James (1969), Rani Singh and Talwar (1978a, 1978b), Jayabalan (1985) and James and Badrudeen (1990), added seven species to the known ponyfish species of India of which four were new to science and three were first reports from India. The most thorough and only comprehensive revision of the family Leiognathidae from the Indian seas was that of James (1975). Jayabalan and Ramamoorthi (1977) gave a synoptic key to the genera of Leiognathidae of Porto Novo and Talwar and Kacker (1984) described 15 species. James (1984) also described 17 species of ponyfish from the Western Indian Ocean including India.

The survey of literature on taxonomy of silverbellies from India clearly reveals that most of the work was carried out from the eastern and southeastern coasts. In the backwaters of Kerala, Shetty (1963) reported 6 species and Kurup and Samuel (1983) reported nine species which brought the total known species from Kerala to 11. Only two species L. equulus and L. brevirostris (now recognized as a junior synonym of Photopectoralis bindus that was long been misidentified as a member of Nuchequula - see Chakrabarty and Sparks 2007) were reported to be abundant. Adequate biometric data is lacking for marine species from the west coast of India. The literature on species 
distribution in different regions in India suggests a great deal of variation in the distribution and abundance of species (James, 1975; Jayabalan and Ramamoorthi, 1977). The distribution of species along the west coast needs to be better understood. Therfore, we felt it necessary to study the taxonomy of the one of the most abundant and misidentified marine taxa found in the sea off Kerala. The taxonomy of silverbellies has changed a great deal in recent years. Several new genera have been established, resurrected, or raised in taxonomic status such as Eubleekeria Fowler, 1904 by Chakrabarty and Sparks 2005, Kimura et al. 2008; Karalla Chakrabarty and Sparks, 2008, Photopectoralis by Sparks, Dunlap and Smith 2005; Nuchequula Whitley, 1932 by Chakrabarty and Sparks 2007; Aurigequula Fowler, 1918 and Equulites Fowler, 1904 elevated to generic rank by Chakrabarty and Sparks, 2008.

\section{Material and methods}

Specimens for the study were collected from the fish landing centers at Cochin and Neendakara, at regular intervals from 1998-2000. After noting the fresh color and pigmentation of the specimens they were injected with $5 \%$ formalin. The specimens were then stored in $5 \%$ formalin. After taking biometric data, the belly was cut open to note the sex. In most species, 30 specimens were examined for describing the species. However in certain species, which are rare in the catches, the descriptions were based on fewer specimens. In taking meristic and morphometric data, the methodology of Hubbs and Lagler (1947) was followed. All the linear measurements were made in the median longitudinal axis. Counts of pectoral rays, pelvic rays and lateral line scales were made on the left side of the specimens. Height of dorsal and anal fins, eye diameter, snout length, head height and height of body were taken using vernier calipers. Counts of lateral line scales and fin rays were made under a binocular stereozoom microscope.

The relationship between certain body length and standard length and between certain dimensions in the head and head length were calculated after ascertaining the type of relationship through a scatter diagram, following the least squares method (Snedecor and Cochran, 1967). Certain body proportions for each species, are expressed as percentages of standard length and certain proportions in the head expressed as percentages of head length are given in the descriptions; the means are given in parentheses following the range for each proportion (the expressions used are predorsal for predorsal length, preanal for preanal length, dorsal base for length of the base of dorsal fin, anal base for length of the base of the anal fin, head for head length, dorsal height for height of the dorsal fin , anal height for height of the anal fin, pectoral for length of the pectoral fin, depth for depth of the body, preorbital for preorbital length and eye for horizontal eye diameter). These measurements useful in comparing and differentiating between morphologically similar species (e.g. Murty, 1978) and comparison of the stocks of the same species from different localities (Lachner and Jenkins, 1971). Since the body proportions are known to vary with growth i.e., the rate of growth of a body part changes with increase in length, a study like this assumes greater importance. Understanding such variations in growth (allometric growth) will help in understanding the intraspecific variations in each species. The frequency distribution of the various meristic characters for each species is given along with the calculated standard deviation and standard error in the Tables. The classification and nomenclature used by Sparks et al. (2005); Chakrabarty and Sparks (2007) and Chakrabarty et al. (2010) was adopted.

\section{Results}

A total of 20 species of Leiognathidae known from the seas around India are listed below; the species collected in this work are shown by one and two asterisks, those marked with ** are the first reports from Kerala coast.

1. Eubleekeria splendens* (Cuvier, 1829)

2. Eubleekeria jonesi James, 1969

3. Nuchequula mannusella* Chakrabarty and Sparks, 2007

4. Nuchequula nuchalis ** (Temminck and Schlegel, 1845)

5. Leiognathus equulus* (Forsskal, 1775)

6. Leiognathus striatus James and Badruddin, 1990

7. Leiognathus rapsoni Munro, 1964

8. Karalla dussumieri $*$ (Valenciennes, 1835) 
9. Karalla daura* (Cuvier, 1829)

10. Photopectoralis bindus*(Valenciennes, 1835)

11. Photopectoralis aureus* (Abe and Haneda, 1972)

12. Equulites absconditus** Chakrabarty and Sparks, 2010

13. Equulites leuciscus** (Günther, 1860)

14. Aurigequula fasciata* (Lacepède, 1803)

15. Aurigequula longispina** (Valenciennes, 1835)

16. Secutor insidiator * (Bloch, 1787)

17. Secutor ruconius* (Hamilton, 1822)

18. Gazza minuta* (Bloch, 1797)

19. Gazza achlamys** Jordan and Starks, 1917

20. Gazza shettyi Jayabalan, 1985

\section{Description of species}

\section{Eubleekeria Fowler 1904}

(Type species: Eubleekeria splendens (Cuvier, 1829))

\section{Eubleekeria splendens (Cuvier, 1829)}

(Plate I, Fig. 1; Tables 1-3)

Leiognathus splendens Cuvier, 1829, Regne Anim, dit., 2a, 2: 212

Material examined. 30 specimens (10 females, 14 males, 6 indeterminates) of 41-108 mm TL (Cochin and Neendakara, Kerala) .

Description. D.VIII - IX, 16; P. ii, 13-14, i - ii; V. I, 5; A. III - 14-15; C. 15-16; L1. 45-57.

As percent of standard length: Total length 135.06-142.86 (138.64); fork length 116.07-123.33 (118.85); predorsal 33.33-40.51 (36.35); preanal 44.44-54.55 (51.25); dorsal base 51.85-70.51 (58.63); anal base 40.00-48.15 (43.56); head 31.34-34.62 (33.21); dorsal height 18.18-24.64 (22.14); anal height 15.69-21.28 (18.74); pectoral 20.90-27.27 (23.66); depth 40.85-55.36 (52.29)

As percent of head length: Snout 22.22-31.58 (26.26); eye 33.33-44.44 (39.11); head height 77.78-95.24 (87.79).

Body compressed and deep. Anterior part of dorsal profile more strongly convex than anterior part of ventral profile. Dorsal profile with a notch above eye. Snout blunt and shorter than eye diameter. Gape of mouth below ventral border of eye. Mandibles slightly concave. Minute villiform teeth in each jaw. Ventral margin of pre-operculum finely serrated. Lateral line prominent and convex from the beginning, but less convex than the dorsal profile. It extends beyond the end of soft dorsal and anal fins, but stops just short of the base of caudal fin. Ventral fin with an axially scale and reaches very near the origin of the anal fin.

Color. Body silvery, abdomen more silvery than back. Back grayish silvery with faint gray wavy vertical lines descending from the dorsum to a little below lateral line. Tip of snout dotted black. Pectoral axil black. Membrane between the second and sixth dorsal spines jet black and the membrane between the following spines, soft dorsal, anal spines, soft anal fin, and the caudal lobes, faint yellow. Tip of caudal lobes dusky.

Distribution. Most widely distributed along the Indian coast, contributing to the fishery, along with other species, especially along the west coast of India. It is known from Veraval, Mangalore, Calicut, Cochin, Mandapam, Porto Novo, Madras, Visakhapatnam and Kakinada.

\section{Nuchequula Whitley, 1932}

(Type species: Equula blochii Valenciennes in Cuvier and Valenciennes, 1835) 

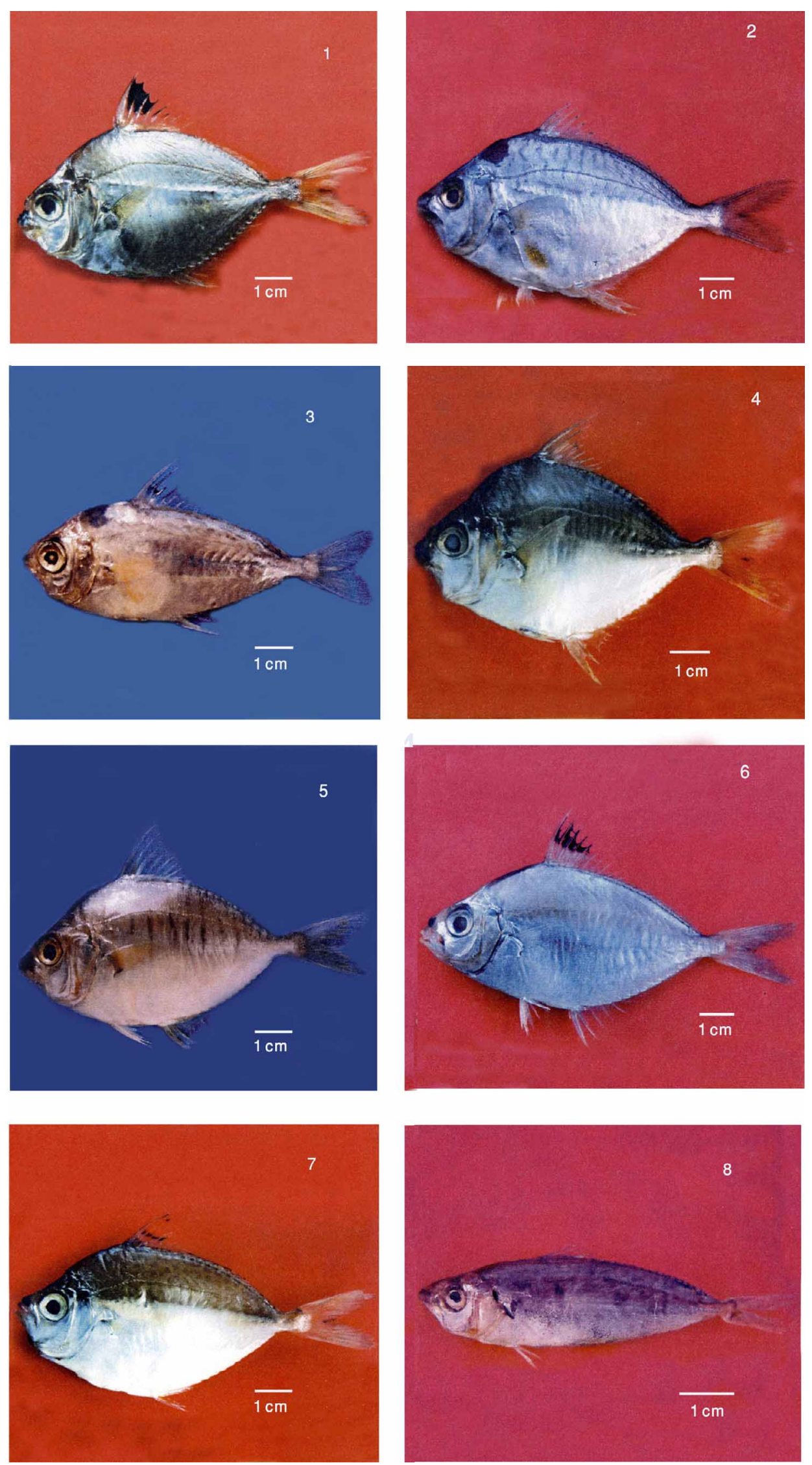

PLATE I. 1. Eubleekeria splendens (Cuvier, 1829); 2. Nuchequula mannusella Chakrabarty and Sparks, 2007; 3. Nuchequula nuchalis (Temminck and Schlegel, 1845); 4. Leiognathus equulus (Forsskal, 1775); 5. Karalla dussumieri (Valenciennes, 1835); 6. Karalla daura (Cuvier, 1829); 7. Photopectoralis bindus (Valenciennes, 1835); 8. Photopectoralis aureus (Abe and Haneda, 1972). 
Equula brevirostris Valenciennes in Cuvier and Valenciennes, 1835, Hist. Nat. poiss., 10 :83.

Material examined. 30 specimens (14 females, 13 males, 3 indeterminates) of $82-114 \mathrm{~mm}$ TL (Cochin, Neendakara).

Description. D.VIII, 16-17; P. ii, 13-15, i - iii; V. I, 5; A. III - 14; C. 15; Ll. 52-64.

As percent of standard length: Total length 131.82-137.31 (134.97); fork length 114.06-118.46 (115.81) ; predorsal 35.53-40.48 (37.66) ; preanal 47.69-52.38 (49.95) ; dorsal base 40.63-57.97 (55.47) ; anal base 38.8145.21 (43.42) ; head 29.85-33.33 (31.37) ; dorsal height 15.56-26.56 (22.70) ; anal height 15.56-20.00 (18.07) ; pectoral 16.42-20.90 (18.87) ; depth 43.75-50.00 (46.19) .

As percent of head length: Snout 26.32-35.71 (30.46) ; eye 30.00-36.84 (32.73); head height 81.82-91.30 (86.22).

Body oval and compressed. Dorsal and abdominal profiles equally convex. Mouth when protracted forms a tube directed downward. Gape of mouth immediately below or opposite to the ventral margin of the eye. The ventral margin of the lower jaw very concave. Teeth small and numerous in a single row in each jaw. Two small spines on dorsal aspect of head opposite the anterior border of eye. The lower margin of the pre-operculum finely serrated. Anterior part of the lateral line concave, ventrally it runs less convex to the dorsal profile extending posteriorly up to the base of the caudal fin. Ventrals with axillary scales and reaches two thirds of the way to the anal fin. Caudal fin deeply forked.

Color. Belly silvery, dorsal body with dark wavy vertical lines extending down to about or slightly ventral to the lateral line, anteriorly to below the origin of dorsal fin and posteriorly to the end of the soft dorsal. A brown blotch on the nape, which becomes diffuse on preservation in formalin. A conspicuous golden yellow patch on belly, about midway between the pelvis and the anal fin origin. Tip of snout, dotted black. The pectoral axil dotted black. Spinous part of the dorsal fin golden at mid height.

Distribution. Occurs along Mangalore, Cochin, Palk Bay, Gulf of Mannar (Mandapam), Kakinada and Godavari estuary. It has also been reported from Vembanad Lake off Cochin. It is abundant in the Rameswaram region.

TABLE 1. Frequency distribution of pectoral fin rays in the silverbellies collected off Kerala coast.

\begin{tabular}{llllllllllll}
\hline Species & \multicolumn{8}{c}{ Pectoral fin rays (Branched + Unbranched) } & \multicolumn{3}{l}{} \\
& 15 & 16 & 17 & 18 & 19 & 20 & 21 & $\mathrm{~N}$ & $\bar{x}$ & $\mathrm{SD}$ & SE \\
\hline E. splendens & - & - & 29 & 1 & - & - & - & 30 & 17.03 & \pm 0.18 & \pm 0.03 \\
N.mannusella & - & - & 1 & 24 & 5 & - & - & 30 & 18.13 & \pm 0.43 & \pm 0.08 \\
P.bindus & 9 & 19 & 2 & - & - & - & - & 30 & 15.77 & \pm 0.57 & \pm 0.10 \\
L.equulus & - & - & - & - & 5 & 20 & 5 & 30 & 20.00 & \pm 0.59 & \pm 0.11 \\
K.dussumieri & - & - & - & 13 & 16 & 1 & - & 30 & 17.97 & \pm 3.24 & \pm 0.59 \\
K.daura & - & - & - & 1 & 8 & 1 & - & 10 & 19.00 & \pm 0.47 & \pm 0.15 \\
N.nuchalis & - & - & 23 & 7 & - & - & - & 30 & 17.23 & \pm 0.43 & \pm 0.08 \\
E.absconditus & - & 10 & - & - & - & - & - & 10 & 16.00 & - & - \\
E.leuciscus & - & - & - & 9 & 1 & - & - & 10 & 18.10 & \pm 0.32 & \pm 0.10 \\
A.fasciata & - & - & - & 1 & 1 & 1 & - & 3 & 19.00 & \pm 1 & \pm 0.58 \\
A.longispina & - & - & - & - & - & - & 1 & 1 & - & - & - \\
P. aureus & - & 2 & - & - & - & - & - & 2 & 14.00 & - & - \\
S.insidiator & - & - & 14 & 16 & - & - & - & 30 & 17.53 & \pm 0.51 & \pm 0.09 \\
S.ruconius & - & - & 11 & 19 & - & - & - & 30 & 17.63 & \pm 0.49 & \pm 0.09 \\
G.minuta & - & 1 & 20 & 9 & - & - & - & 30 & 17.27 & \pm 0.52 & \pm 0.10 \\
G.achlamys & - & - & 5 & - & - & - & - & 5 & 17.00 & - & -
\end{tabular}


Equula blochii Valenciennes, in Cuvier and Valenciennes, 1835, Hist. Nat. poiss., 10: 84.

Material examined. 30 specimens (11 females, 10 males, 9 indeterminate) of 71- 94 mm TL (Cochin, Neendakara).

Description. D.VIII, 15-16; P. ii, 12-14, i-iii; V. I, 5; A. II, 14; C. 15. L1. $49-57$.

As percent of standard length: Total length 131.34-136.54 (133.74); fork length 112.96-118.75 (115.78); predorsal 34.55-38.89 (36.78); preanal 46.55-52.24 (49.74); dorsal base 55.07-58.18 (56.17); anal base 40.30-44.62 (43.10); head 27.59-31.03 (29.28); dorsal height 19.70-24.07 (21.93); anal height 17.91-21.74 (19.57); pectoral 17.91-23.08 (20.45); depth 36.21-42.59 (39.72).

As percent of head length: Snout 22.22-30.00 (25.98); eye 27.78-37.50 (32.58); head height 80.00-88.89 (84.24).

Body oval, compressed, rather elongate. Dorsal and ventral profiles almost equally convex, the former evenly curved from tip of snout to origin of dorsal fin. Snout pointed. Mouth small, lips narrow and thin. Mouth when protracted forms a tube directed downwards. Gape of mouth opposite lower third of eye. Lower jaw strongly concave. Teeth small, numerous, villiform, in each jaw. Two small spines on top of the head opposite front border of the eye. Pre-opercle with a finely serrated lower margin. First part of the lateral line shows concavity, later running less convex to the dorsal profile, extending posteriorly to the base of the caudal fin. Ventrals not reaching half way to the anals and with axillary scales. Caudal deeply forked.

Color. Abdomen more silvery than back, with black irregular bands extending to about half level. Light brown blotch on nape, which covers an area from about the posterior half of the nuchal spine to the origin of the dorsal fin. Membrane from above the half level to the tip of spines between the second to the seventh dorsal spines black. Tip of snout dotted black. Fine black dots on ventral half of the body. Inner side of the pectoral, posteriorly dark coloured. Gill opening area covered by the lower half of the operculum also dotted black.

Distribution. Known from off Cochin, Quilon, Madras, Kakinada, and Calcutta and in Sunder bans and Chalk Lake.

\section{Leiognathus Lacepède, 1803}

(Type species: Leiognathus argenteus Lacepède, 1803)

(= Scomber eduntulus Bloch, 1785)

\section{Leiognathus equulus (Forsskål, 1775)}

(Plate I, Fig. 4; Tables 1-3)

Scomber equula Forsskål, 1775, Descr. Animal, p.75

Material examined. 30 specimens (6 females, 23 males, 1 indeterminate) of 79-126 mm TL (Cochin, Neendakara).

Description. D.VIII, 16-17; P. ii, 15-17, i - iii; V. I, 5; A. III, 13-14; C. 15; Ll. 54-64.

As percent of standard length: Total length 134.88-142.68 (137.73); fork length 115.12-120.73 (117.40); predorsal 37.21-43.75 (40.17); preanal 48.84-54.88 (51.45); dorsal base 50.72-56.18 (53.54); anal base 40.00-45.00 (42.58); head 31.40-35.94 (33.50); dorsal height 22.09-27.78 (24.70); anal height 18.99-22.22 (20.48); pectoral 20.00-26.09 (23.22); depth 53.45-60.00 (56.80).

As percent of head length: Snout 28.57-35.71 (32.18); eye 31.25-37.93 (35.20); head height 88.89-104.35 (95.21). 


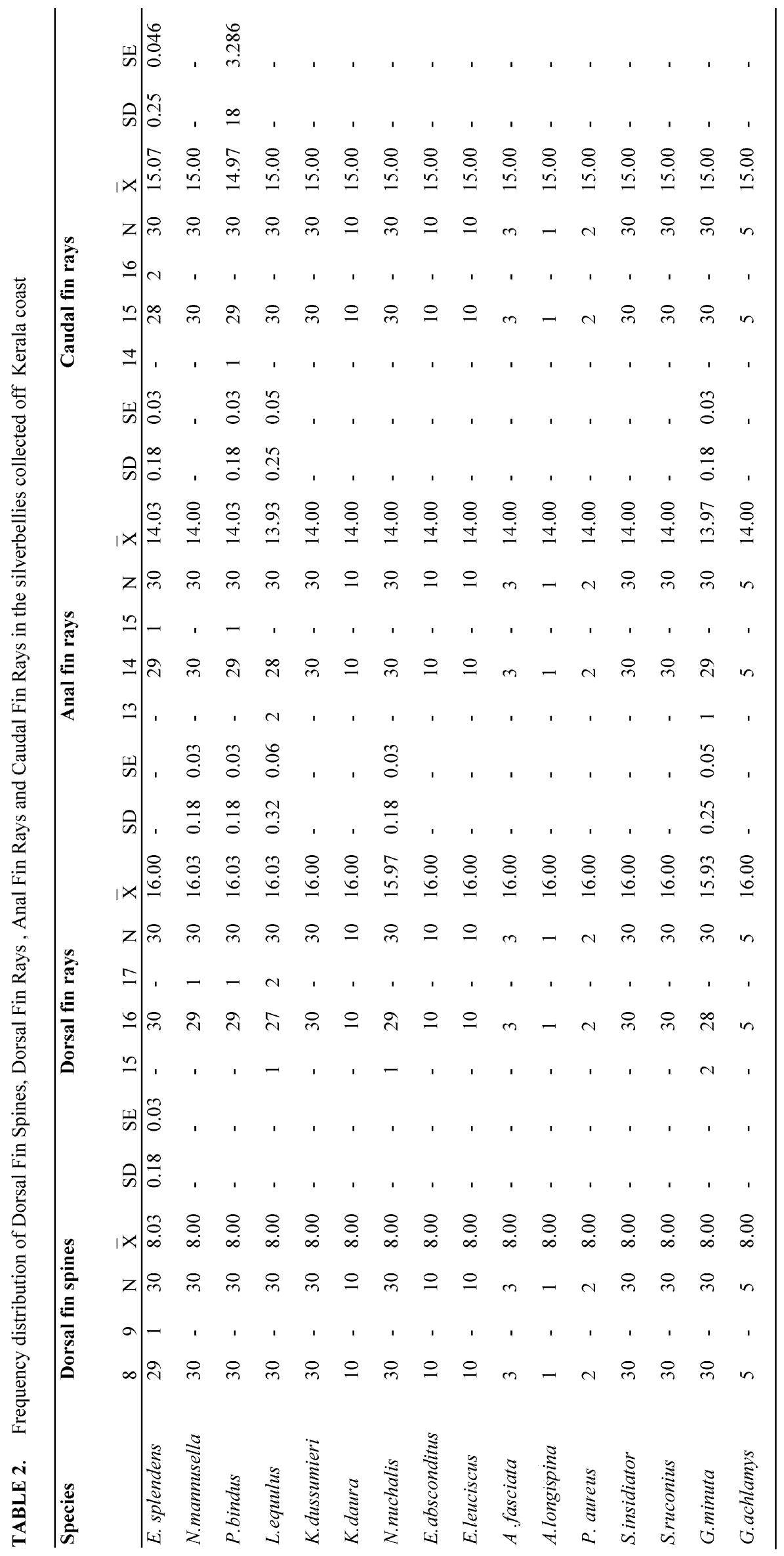


Body oblong, deep and compressed. Dorsal profile more convex than the ventral profile; gently elevated from the occipital region to form a strongly humped back. Snout blunt. Mouth with thick lips. Mouth pointing downwards when protracted. Commencement of gape of mouth below lower border of eye. Lower margin of lower jaw strongly concave. Teeth small, numerous, villiform, in each jaw. Two small spines on top of the head, opposite front border of the eye. Pre-opercle with its lower margin slightly concave and serrated. Lateral line, conspicuous, concave at first, later on becomes convex, but less convex than the dorsal profile, and extends almost up to the base of the caudal fin. Ventrals do not reach the origin of the anal fin and has a prominent axillary scale, and a strong spine. Caudal fin not deeply forked and with rounded lobes.

Color. Body silvery, back grayish. Close set fine vertical bands descend from back to about mid height, clearly seen in fresh specimens, but fade on preservation in formalin. Membrane between anal spines yellowish. Snout dotted black. Pectoral fin axil faintly dusky. Posterior margin of caudal lobes pale yellow and dusky.

Distribution. Along Bombay, Mangalore, Calicut, Cochin, Quilon, Cape Comorin, Mandapam, Rameswaram, Kilakarai, Pamban, Madras, Porto Novo, Visakhapatnam, Kakinada. Also found in Godavary estuary and Chilka Lake.

TABLE 3. Frequency distribution of lateral line scales in the silverbellies collected off Kerala coast.

\begin{tabular}{|c|c|c|c|c|c|c|c|c|c|c|c|c|c|c|c|c|}
\hline \multirow[t]{2}{*}{ Species } & \multicolumn{16}{|c|}{ Lateral Line Scales } \\
\hline & 45 & 46 & 47 & 48 & 49 & 50 & 51 & 52 & 53 & 54 & 55 & 56 & 57 & 58 & 59 & 60 \\
\hline E. splendens & 1 & - & 2 & 4 & 2 & 1 & 5 & 4 & 4 & 4 & 1 & 1 & 1 & - & - & - \\
\hline N.mannusella & - & - & - & - & - & - & - & 1 & 1 & - & 3 & 2 & 6 & 2 & 5 & 3 \\
\hline L. equulus & - & - & - & - & - & - & - & - & - & 2 & - & 4 & 5 & 7 & 3 & 4 \\
\hline K. dussumieri & - & - & - & - & - & - & 1 & - & - & 1 & 4 & 6 & 8 & 3 & 5 & 2 \\
\hline K. daura & - & - & - & - & - & - & - & - & - & - & - & - & - & - & - & - \\
\hline N. nuchalis & & - & - & - & 1 & 1 & - & 1 & - & 1 & 2 & 10 & 14 & - & - & - \\
\hline E. leuciscus & - & - & - & - & - & - & - & - & - & - & - & - & - & - & - & - \\
\hline A. fasciata & - & - & - & - & - & - & - & - & - & - & - & - & - & - & - & - \\
\hline A.longispina & - & - & - & - & - & - & - & - & - & - & - & - & - & - & - & - \\
\hline G. minuta & - & - & - & - & - & - & - & - & - & - & - & - & 3 & 23 & 4 & - \\
\hline
\end{tabular}

continued.

\begin{tabular}{|c|c|c|c|c|c|c|c|c|c|c|}
\hline \multirow[t]{2}{*}{ Species } & \multicolumn{10}{|c|}{ Lateral Line Scales } \\
\hline & 61 & 62 & 64 & 66 & 67 & 69 & $\mathrm{~N}$ & $\bar{x}$ & SD & SE \\
\hline E. splendens & - & - & - & - & - & - & 30 & 51.27 & 2.900 & 0.529 \\
\hline N.mannusella & 4 & 2 & 1 & - & - & - & 30 & 58.23 & 2.760 & 0.504 \\
\hline L. equulus & 2 & 2 & 1 & - & - & - & 30 & 58.33 & 2.310 & 0.422 \\
\hline K. dussumieri & - & - & - & - & - & - & 30 & 56.87 & 1.925 & 0.351 \\
\hline K. daura & - & - & 1 & 4 & 4 & 1 & 10 & 66.50 & 1.269 & 0.401 \\
\hline N. nuchalis & - & - & - & - & - & - & 30 & 55.77 & 2.029 & 0.370 \\
\hline E. leuciscus & 5 & - & 5 & - & - & - & 10 & 62.50 & 1.581 & 0.500 \\
\hline A. fasciata & - & 3 & - & - & & - & 3 & 62.00 & - & - \\
\hline A.longispina & 1 & - & - & - & - & - & 1 & 61.00 & - & - \\
\hline G. minuta & - & - & - & - & - & - & 30 & 58.03 & 0.490 & 0.089 \\
\hline
\end{tabular}

Karalla Chakrabarty and Sparks, 2008

(Type species: Karalla daura Cuvier, 1829) 
Equula dussumieri Valenciennes 1835, in Cuvier \& Valenciennes, Hist. Nat. Poiss., 10: 77.

Material examined. 30 specimens ( 8 females, 13 males, 9 indeterminate) of 71-130 mm TL (Cochin, Neendakara).

Description. D.VIII, 16; P. ii, 14-15, i - iii; V. I, 5; A. III, 14; C. 15; Ll. 51-60.

As percent of standard length: Total length 131.31-137.84 (134.70); fork length 115.05-118.97 (116.58); predorsal 35.71-38.46 (37.14); preanal 46.43-53.54 (50.27); dorsal base 55.26-58.21 (56.81); anal base 40.40-45.61 (43.37); head 29.82-34.21 (31.74); dorsal height 17.54-26.87 (23.65); anal height 14.55-20.55 (18.00); pectoral 19.18-23.29 (20.91); depth 43.21-49.49 (46.97).

As percent of head length: Snout 23.53-34.48 (29.49); eye 30.77-40.91 (34.07); head height 76.92-88.24 (81.01).

Body oblong, moderately compressed, dorsal and ventral profiles equally convex. Dorsal profile elevated and curved behind occipital profile and separated from it by a gentle concavity. Snout blunt. Mouth small and when protracted directed downwards. Commencement of gape of mouth below lower margin of eye. Mandibles slightly concave inferiorly. Teeth small, numerous, villiform, in each jaw. Two small spines on top of the head, opposite the front border of the eye. Pre-opercle with its lower margins finely serrated. Lateral line begins with a concavity and runs less convex than the dorsal profile, extending beyond the end of the soft dorsal and anal fins, but stops just short of the base of the caudal fin. Ventrals do not quite reach the anals, stopping just short. Ventrals with a strong spine and a large axillary scale. Caudal forked with rounded lobes.

Color. Abdomen silvery, back brownish. Sides of body with dark, narrow, wavy vertical lines descending from the back to a little beyond lateral line, often fading on keeping in formalin. An elongate yellow spot on belly below pectoral fin. Base of pectoral fin dark.

Distribution. It is known from off Cochin, Quilon, Tuticorin, Pamban, Mandapam, Kakinada, and Visakhapatnam. It is most dominant in southern Tamilnadu, in the Gulf of Mannar off Mandapam, Tuticorin and Pamban.

\section{Karalla daura (Cuvier, 1829)}

(Plate I, Fig. 6; Tables 1-3)

Equula daura Cuvier, 1829, Regne Anim.,2 : 212.

Material examined. 10 specimens ( 2 females, 3 males, 5 indeterminates) of 56-136 mm TL (Cochin, Neendakara).

Description. D.VIII, 16; P. ii, 14-16, i-iii; V. I, 5; A. III, 14; C. 15; Ll. 64-69.

As percent of standard length: Total length 130.23-135.63 (133.54); fork length 113.46-116.67 (114.68) predorsal 37.04-40.59 (38.89); preanal 47.92-54.46 (50.66); dorsal base 52.08-55.00 (53.45); anal base 39.60-45.83 (42.62); head 26.79-30.77 (28.70); dorsal height 18.60-25.29 (20.97); anal height 13.86-17.24 (15.03); pectoral 16.28-19.80 (18.18); depth 37.21-47.52 (42.33).

As percent of head length: Snout 25.00-31.25 (28.60); eye 30.77-39.13 (34.22); head height 78.57-88.0 (83.18).

Body elongated and compressed. Dorsal and ventral profiles equally convex. Occipital region with a concavity and the dorsal profile rises from this region to the spinous dorsal. Snout blunt. Mouth small with thick broad lips and pointing downwards when protracted. Commencement of gape of mouth opposite lower one third of the eye. Inferior margin of the lower jaw slightly concave. Pre-opercle with its lower margin finely serrate. Teeth small and numerous, on both the jaws. Two small spines on top of the head, opposite the front border of the eye, the outer one more prominent than the inner which is opposite the ridge bounding the interorbital space. First part of the lateral line with a concavity, later running less convex than the dorsal profile, extending posteriorly to the base of the caudal fin. Ventrals with a strong spine and a large axillary scale and do not reach the anal fin. Caudal forked.

Color. Abdomen silvery and back gray. Black dots all over the ventral half of the body. Tip of snout black. Inner side of pectoral base gray. A deep black blotch on the upper half of the spinous dorsal, extending from the 
posterior margin of the second dorsal spine to the anterior margin of the sixth dorsal spine. A broad yellow band over the lateral line from the posterior margin of the eye to the caudal base, distinct in fresh specimens, but disappearing gradually on keeping in formalin. Anal fin golden yellow from the second spine onwards along the distal half of the fin. A black line running along the base of the soft dorsal.

Distribution. Along Goa, Cochin and Quilon along the west coast of India and Palk Bay, Gulf of Mannar, Chilka lake, Kakinada and Porto Novo along the east coast.

\section{Photopectoralis Sparks, Dunlap and Smith, 2005}

(Type species: Leiognathus aureus Abe and Haneda, 1972

\section{Photopectoralis bindus (Valenciennes, 1835)}

(Plate I, Fig. 7; Tables 1-2)

Equula bindus Valenciennes 1835, in Cuvier \& Valenciennes, Hist. Nat. Poiss., 10 : 78.

Material examined. 30 specimens (6 females, 9 males, 15 indeterminates) of 50-106 mm TL (Cochin and Neendakara).

Description. D.VIII, 16; P. ii, 11-13, ii - iii; V. I, 5; A. III - 14; C. 14-15.

As percent of standard length: Total length 128.95-139.66 (135.80); fork length 112.33-117.24 (114.72); predorsal 31.25-37.25 (34.61); preanal 42.31-48.65 (46.45); dorsal base 56.86-61.70 (59.35); anal base 44.74-50.91 (47.28); head 26.92-30.99 (29.11); dorsal height 15.69-21.43 (18.53); anal height 12.50-17.91 (15.17); pectoral 17.65-22.97 (20.89); depth 48.65-57.14 (54.24).

As percent of head length: Snout 18.18-26.67 (23.28); eye 35.00-45.00 (39.94); head height 90.91-110.53 (102.58).

Body deep oval and strongly compressed, particularly in the lower part. Ventral profile of the body more markedly convex than the dorsal profile. Abdomen before anal more strongly convex. Occipital profile shows a slight concavity and gradually rises to the dorsal profile. Protracted mouth parts point forward to slightly downward. Commencement of the gape of mouth somewhat above level of lower border of eye. Mandible slightly concave. Teeth small, numerous, in both the jaws. Two small spines on top of the head, opposite the front border of the eye. Pre-opercle with its lower margin finely serrate. First part of the lateral line straight, later running less convex to the dorsal profile and ending below the middle of the soft dorsal, posteriorly lateral line becoming obsolete. Ventrals short, their tips scarcely reaching half way to the anals. Ventral fin with a long axillary scale. Caudal fin deeply forked with spreading pointed lobes. Dorsolateral lobes of light organs hypertrophied about pectoral-axil window.

Color. Body silvery, abdomen more silvery than back. Dark irregular, somewhat vermiculate or semicircular markings in a zigzag pattern, commencing immediately behind head and extending to the end of the soft dorsal, laterally extending down to less than half height. In males with flank patch in the region behind the pectoral fin is translucent, whereas in females it is covered in silvery white as in the remainder of the body. Spinous part of dorsal fin, black at half height, above which the membrane between the second and fifth spines bears a bright orange blotch which turns yellow on preservation in formalin. Tip of snout and ventral half of body with grey dots. Pectoral axil dotted black. Faint yellow colour on basal part of spinous anal fin membrane. Caudal especially its posterior margins are dusky.

Distribution. Widely distributed along both the coasts, along Veraval, Mangalore, Calicut, Cochin, Palk bay, Gulf of Mannar, Madras, Kakinada, Visakhapatnam and West Bengal. It forms a significant part of silverbelly fishery in Gujarat, Tamilnadu.

\section{Photopectoralis aureus (Abe and Haneda, 1972)}

(Plate I, Fig. 8; Tables 1-2)

Equula elongata Günther, 1874, Ann. Mag. Nat. Hist., 4(14):369. 
Material examined. 2 specimens (both indeterminates) of 71-77 mm TL (Neendakara).

Description. D.VIII, 16; P. ii, 12, ii; V. I, 5; A. III, 14; C. 15.

As percent of standard length: Total length 126.23-126.79 (126.51); fork length 113.11-114.29 (113.70); predorsal 37.50-37.70 (37.60); preanal 52.46-53.57 (53.02); dorsal base 55.74-57.14 (56.44); anal base 40.98-41.07 (41.03); head 29.51-30.36 (29.93); dorsal height (12.50); anal height 7.14-8.20 (7.67); pectoral 14.29-16.39 (15.34); depth 21.43-24.59 (23.01).

As percent of head length: Snout 27.78-29.41 (28.59); eye 27.78-29.41 (28.59); head height 52.94-61.11 (57.03).

Body elongate, slender and moderately compressed. Dorsal and ventral profiles, almost evenly curved and tapering gently to the very short caudal peduncle. Upper surface of head weakly convex. Snout sharp, pointed. Protracted mouth parts point downwards. Narrow band of small teeth in each jaw. Mandibular slightly concave. Lateral line conspicuous at the beginning, but could not be clearly traced thereafter, for the lateral line scales to be counted. Caudal fin deeply forked. Ventrals reaching halfway to the anals. The light organs of males is twenty times longer than conspecific females of similar SL.

Color. Body silvery, back and sides marked with a number of irregular, dark, brownish spots and vermiculations. Underside of pectoral fin with minute dark dots. A black spot at the base of each dorsal and anal ray. Anal fin between second and third spines yellow, as also the margin of the anterior part of the fin. Lower half of the body covered with fine black dots on the sides, the dots on the upper half of the body minute, but just as numerous. Edge of the gill opening on the lower side, covered by the opercular flap also dotted black.

Distribution. Occurs only in stray catches along the coast.

\section{Equulites Fowler, 1904}

(Type species: Leiognathus vermiculatus Fowler, 1904)

\section{Equulites absconditus Chakrabarty and Sparks, 2010}

(Plate II, Fig. 1; Tables 1-2)

Equula lineolata Valenciennes in Cuvier and Valenciennes, 1835, Hist. nat. Poiss., 10: 86.

Material examined. 10 specimens ( 2 females, 4 males, 4 indeterminates) of 54-76 mm TL (Cochin, Neendakara).

Description. D.VIII, 16; P. ii, 11-12, ii; V. I, 5; A. III, 14; C. 15.

As percent of standard length: Total length 128.81-132.00 (130.48); fork length 112.77-116.07 (114.52); predorsal 35.42-37.50 (36.49); preanal 46.67-50.00 (48.67); dorsal base 55.36-59.57 (57.04); anal base 42.55-45.83 (44.18); head 26.67-29.17 (27.87); dorsal height 15.56-18.00 (17.06); anal height 12.20-14.58 (13.13); pectoral 16.67-18.00 (17.29); depth 31.71-40.00 (36.97).

As percent of head length: Snout 21.43-31.25 (26.62) ; eye 31.25-38.46 (34.00) ; head height 71.43-81.82 (76.17).

Body oblong, compressed and elongate, dorsal and ventral profiles equally convex. A slight concavity over occiput. Snout pointed. Mouth small, lips narrow and thick. Mouth when protracted forms a tube directed downwards. Commencement of gape of mouth over lower one third of eye. Inferior edge of mandibles slightly concave. Teeth small, numerous, on the jaws. A pair of spines on top of the head, over the anterior third of the orbit. Preopercle with its lower margin straight and finely serrated. First part of lateral line with a concavity, later running less convex to the dorsal profile, and cannot be traced forward from somewhere between the middle to the end of the dorsal fin, posteriorly. Ventrals with axillary scale and their tips do not quite reach the origin of the anals. Caudal fin deeply forked. In males, an expansive triangular translucent patch in the shape of an equilateral triangle is present in the midflank.

Color. Belly silvery, back brownish with relatively sparse vertical zigzag lines or grey irregular vermiculations from behind head to caudal base, laterally extending down to a little below the lateral line. Ventral half of the body with fine black dots. Tip of snout dotted black. Inner side of pectoral base also dotted black, as also the lower edge of the gill opening covered by the opercular flap.

Distribution. Along Cochin, Quilon, Palk Bay and Gulf of Mannar, Madras, and Kakinada. 

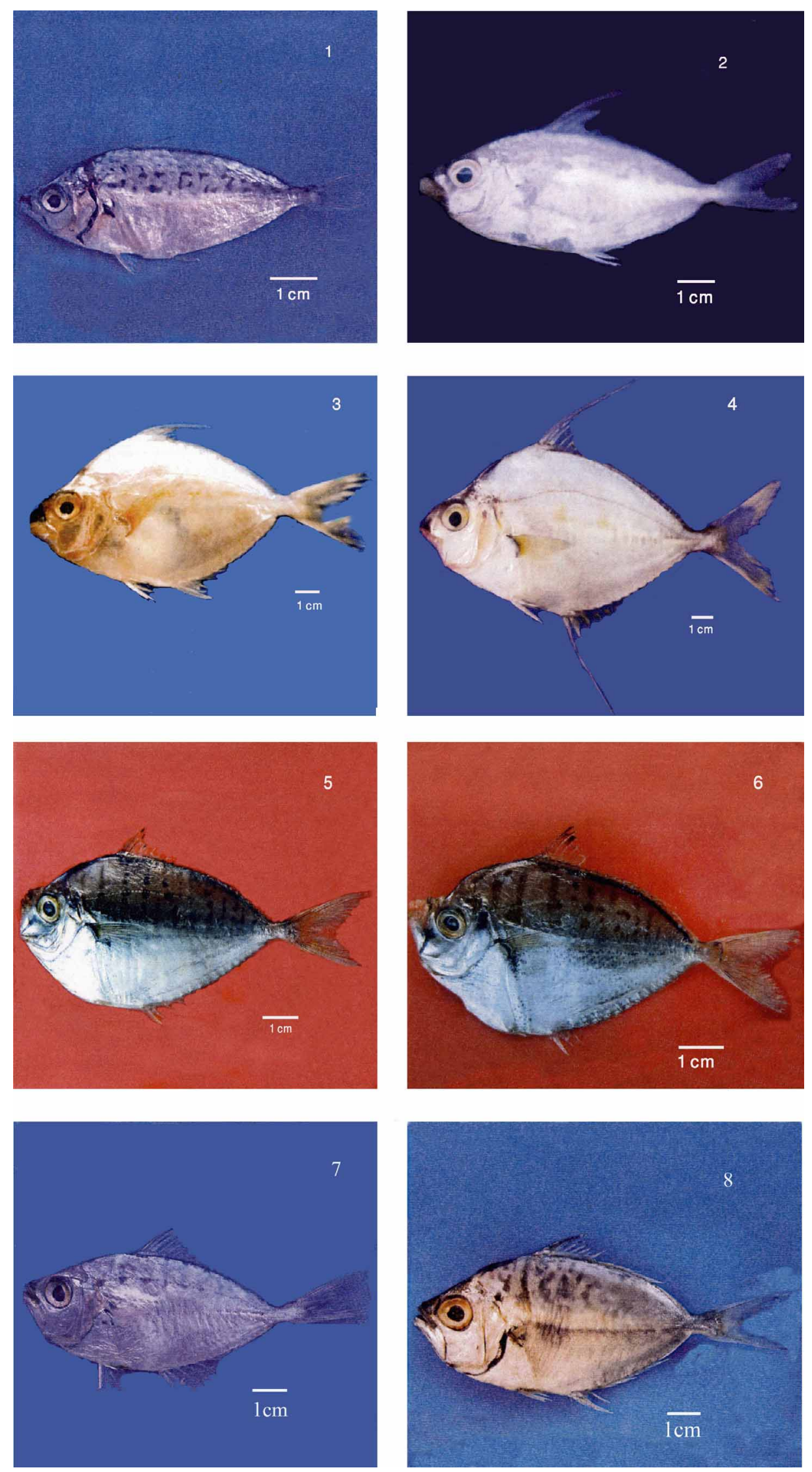

PLATE II. 1. Equulites absconditus Chakrabarty and Sparks, 2010; 2. Equulites leuciscus (Günther, 1860); 3. Aurigequula fasciata (Lacepède, 1803); 4. Aurigequula longispina (Valenciennes, 1835); 5. Secutor insidiator (Bloch, 1787); 6. Secutor ruconius (Hamilton, 1822); 7. Gazza minuta (Bloch, 1797); 8. Gazza achlamys Jordan and Starks, 1917. 
Equula leuciscus Günther, 1860. Cat. Brit. Mus., 2: 503.

Material examined. 10 specimens ( 5 females, 4 males, I in determinant) of 77-134 mm (Cochin, Neendakara).

Description. D.VIII, 16; P. ii, 13-14, iii; V. I, 5; A. III, 14; C. 15; Ll. 61-64.

As percent of standard length: Total length 128.77-135.09 (131.37); fork length 113.04- 116.28 (114.40); predorsal 36.23-38.46 (37.37); preanal 49.12-55.77 (50.92); dorsal base 54.10-58.14 (55.88); anal base 38.46-44.26 (42.24); head 26.25-28.85 (27.87); dorsal height 21.05-27.54 (24.72); anal height 15.79-20.51 (17.52); pectoral 15.94-17.91 (16.71); depth 36.07-41.86 (39.06).

As percent of head length: Snout 28.57-33.33 (30.41); eye 29.17-37.50 (32.58); head height 76.19-85.71 (79.78).

Body compressed and elongate. Dorsal profile somewhat more convex than the ventral. Upper profile of head rises back with a little concavity. Snout pointed. Mouth small pointing downwards when protracted. Cleft of mouth opposite middle to lower third of eye. Mandibular profile slightly concave. Two spines on the supraorbital edge of the eye. Villiform teeth present in each jaw. Lateral line extends beyond soft dorsal and anal fins, up to the base of the caudal fin. Second dorsal spine elongated and filiform, upper half of which is flexible. The second dorsal spine when flexed backwards extends up to the second to the fourth dorsal ray (only 3 specimens examined for this character, since in all the others the second dorsal spine was broken), i.e. well in front of the middle of the soft dorsal. The third dorsal spine is only about half the length of the preceding. The anal fin commences vertically below the eighth dorsal spine. Ventral fins reaching only to about two-thirds of the distance to the anal fin origin. Caudal forked. Dorsolateral lobes of light organs hypertrophied, extend posteriorly into gas bladder.

Color. Body silvery, back and sides marked with a number of irregular semicircular and undulated, dark, graybrown spots and vermiculations. Yellow spots below lateral line on large specimens, fading almost completely on preservation in formalin. Pectoral axil, black with minute dots. Membrane between dorsal fin spines soft yellow at mid height, edge of soft part of dorsal fin also yellow. Posterior part of caudal fin also yellowish.

Distribution. Distributed off Cochin, Quilon, Palk Bay, Gulf of Mannar and Madras.

\section{Aurigequula Fowler, 1918}

(Type species: Clupea fasciata Lacepède, 1803)

\section{Aurigequula fasciata (Lacepède, 1803)}

(Plate II, Fig. 3; Table 1-3)

Clupea fasciata Lacepède, 1803, Hist. Nat. Poiss., 5: 460,463

Material examined. 3 specimens (2 males, 1 indeterminate) of $111 \mathrm{~mm}-129 \mathrm{~mm}$ SL (Cochin, Neendakara).

Description. D.VIII, 16; P. ii, 14-16, ii; V. I, 5; A. III, 14; C. 15. L1. 62.

As percent of standard length: Total length 134.48-136.04 (135.26); fork length 113.79-115.32; predorsal 38.76-39.64 (39.06); preanal 49.61-52.59 (51.48); dorsal base 55.17-55.86 (55.61); anal base 41.38-44.96 (43.19); head 31.01-32.43 (31.49); dorsal height 39.66; anal height (20.93); pectoral 22.41-22.52 (22.47); depth 54.95-56.59 (55.57).

As percent of head length: Snout 33.33-35.00 (33.89); eye 35.00-36.11; head height 86.11-91.67 (88.43).

Body compressed, ovate and deep. Back more strongly arched than anterior part of belly. Mouth horizontal and when protracted forming a tube with downward direction. Gape of mouth when closed opposite and below the lower margin of the eye. Mandible slightly concave inferiorly. Narrow band of villiform teeth in each jaw. A pair of spines above the anterior superior angle of the orbit. Pre-opercular with its lower margin finely serrated. Lateral line, very slightly concave at commencement and convex thereafter, but less so when compared to the dorsal profile, and extends up to a little distance short of the base of the caudal fin. Second dorsal spine filiform, its tip 
extending up to the origin of the eighth dorsal ray, when flexed backward (only one specimen examined for this character). Second anal spine somewhat elongate, but not as long as the second dorsal. Ventrals with prominent axillary scale (its tip reaching the tip of the innermost rays). Ventrals does not reach the origin of the anal. Caudal deeply forked. This species bears moderately enlarged light organs. No sexually dimorphic with respect to internal or external features of the LOS.

Color. Abdomen and back silvery. Upper half with indistinct gray-brown vertical bands descending up to a little beyond the lateral line, numbering ten to fifteen. In between lateral line and median line of the body a few big oval yellow blotches are present in addition to a few smaller ones of the same hue. Inner side of pectoral base dotted black. Spinous anal fin with faint yellow colouring, continued marginally along the rays. Caudal fin dusky.

Distribution. Along Cochin, Quilon, Gulf of Mannar and Palk Bay. It does not form a fishery of any importance anywhere along the coast.

\section{Aurigequula longispina (Valenciennes, 1835)}

(Plate II, Fig. 4; Tables 1-3)

Leiognathus longispina Valenciennes, 1835, Proc. Linn. Soc. N. S. Wales (2) 1: 11.

Material examined. 1 specimen, male, $115 \mathrm{~mm}$ TL (Cochin).

Description. D.VIII, 16; P. ii, 17, ii; V. I, 5; A. III, 14; C. 15. Ll. 61.

As percent of standard length: Total length 133.72; fork length 117.44; predorsal 37.21; preanal 51.16; dorsal base 58.14; anal base 44.19; head 30.23; dorsal height 41.86; anal height 45.35; pectoral 22.09; depth 56.98.

As percent of head length: Snout 30.77; eye 34.62 ; head height 92.31 .

Body oval and compressed. Anterior part of the dorsal profile more strongly arched than anterior part of the ventral profile. The upper profile of the head with a gentle concavity. Snout blunt. Mouth small and pointing downward when protracted. Cleft of mouth above lower edge of eye. Mandibles inferiorly slightly concave. Teeth small, numerous and villiform. Two small spines above the anterior superior angle of the orbit. Pre-operculum with its lower margin distinctly and finely serrated. Lateral line strongly convex, extends beyond end of soft dorsal and anal, but stops a short distance in front of the caudal fin. Second spines of dorsal and anal fin greatly elongated. The second dorsal spine reaches up to the sixth dorsal ray and the ventral spine up to the fifth dorsal ray (only one specimen examined).

Color. Abdomen more silvery than back, which shows a few, faint, unevenly spaced horizontally elongate grey brown streaks or blotches. Variable number of yellow blotches along the flank below the lateral line. Soft anal and margin of soft dorsal fin yellow. Underside of the pectoral fin base dotted black. Tip of snout gray. Margin of caudal lobes dusky.

Distribution. Only stray catches are reported from Palk Bay and Kakinada. Reported from Cochin for the first time, in the present work.

\section{Secutor Gistel, 1848}

(Type species: Zeus insidiator Bloch, 1787)

\section{Secutor insidiator (Bloch, 1787)}

(Plate II, Fig. 5; Tables 1-2)

Zeus insidiator Bloch 1787, Ausl. Fische, 3: 41, pl. 192, fig.2-3.

Material examined. 30 specimens (14 females, 12 males, 4 indeterminates) of 47-106 mm TL (Cochin, Neendakara).

Description. D.VIII, 16; P. ii, 13-15, i-iii; V. I, 5; A. III, 14; C. 15.

As percent of standard length: Total length 127.94-134.48 (131.96); fork length 111.54-117.14 (113.89); pre- 
dorsal 35.71-38.89 (37.03); preanal 42.50-46.91 (45.25); dorsal base 52.78-58.93 (56.30); anal base 46.05-51.43 (48.07); head 26.23-28.57 (27.24); dorsal height 13.89-18.18 (16.39); anal height 8.75-12.50 (10.86); pectoral 19.44-23.08 (21.48); depth 41.67-50.72 (47.48).

As percent of head length: Snout 20.00-28.57 (25.04); eye 29.41-40.00 (33.59); head height 110.00-122.73 (117.62).

Body oval, deep, elongated and compressed. Dorsal profile less convex than the ventral profile and the dorsal profile strongly concave in the occipital region. Snout pointed. Mouth small and oblique, when protracted forms a tube directed upwards. Gape of mouth opposite about middle of eye. Mouth small, lips broad and thin. Lower lip broader and smaller than the upper lip, which is like a loop over the lower. When mouth is closed, the mandible is almost vertical. Lower margin of the mandible slightly concave. Teeth minute, numerous and villiform. One small spine on head, immediately above the eye and opposite its front border. Lateral line shows a slight concavity at first, later running less convex to the dorsal profile extending posteriorly almost to the base of the caudal. Ventrals with axillary scales, their tips reaching only halfway to the origin of the anals. Caudal fin deeply forked. Ventrolateral lobes of light organ hypertrophied.

Color. Silvery, back with about ten or so black, vertical bands, formed of patches, from behind head to end of soft dorsal, laterally extending to a little below the lateral line. Abdomen with black pigment spots. Spinous dorsal fin with the membranes between the second to the sixth spines black at the upper one third portion. A black curved band from the lower margin of the eye to the posterior angle of the lower jaw. Inner side of pectoral base dotted black. Caudal fin yellowish and posterior margin of the lobes are dusky.

Distribution. Along Mangalore, Cochin, Quilon, Mandapam, Madras, Visakhapatnam and Kakinada. It forms the dominant fishery at Mangalore and contributes heavily at Madras, Kakinada and Cochin.

\section{Secutor ruconius (Hamilton-Buchanan, 1822)}

(Plate II, Fig. 6; Tables 1-2)

Chanda ruconius Hamilton-Buchanan, 1822, Fish. Ganges, P. 106, 371, pl.126, fig.35.

Material examined. 30 specimens ( 7 females, 9 males, 14 indeterminates) of 42-83 mm TL (Cochin, Neendakara).

Description. D.VIII, 16; P. ii, 12-14, i-ii; V. I, 5; A. III, 14; C. 15.

As percent of standard length: Total length 130.77-140.00 (135.19) ; fork length 110.26-118.75 (115.28) ; predorsal 35.48-40.91 (38.28) ; preanal 40.63-47.17 (43.92) ; dorsal base 52.27-57.41 (54.87) ; anal base 46.8151.85 (49.61) ; head 26.42-30.77 (28.93) ; dorsal height 15.63-20.37 (17.47) ; anal height 10.34-13.95 (12.19) ; pectoral 20.93-25.00 (22.68); depth 56.41-62.75 (59.57).

As percent of head length: Snout 18.18-28.57 (24.28); eye 30.00-42.86 (37.15); head height 125.00-144.44 (134.66).

Body oval, strongly compressed and deep. Ventral profile, much more convex than the dorsal profile. Rostrooccipital line of the head concave. Mouth small, oblique, lips broad and thin, lower lip smaller and broader than the upper. Mouth when protracted forms a tube directed upwards. Gape of mouth opposite middle level of the eye. Lower margin of lower jaw slightly concave and at right angles to the mouth slit. Teeth minute, numerous and in a villiform band. One small spine on head. Pre-opercle with its lower margin finely serrate. Lateral line convex from the beginning later runs less convex to the dorsal profile, often indistinct from the middle of the soft dorsal. Ventrals with axillary scales and do not reach even half way to the anals. Caudal deeply incised, lobes pointed. Ventrolateral lobes of light oragns hypertrophied.

Color. Body silvery with about ten or so black or gray vertical bands on the back, extending to a little below the lateral line, anteriorly commencing below tip of the nuchal spine and posteriorly extending up to the end of the soft dorsal, and often the lines are in continuous patches. Membrane between the second and fifth dorsal spines black in the upper one third portion. A prominent curved black band running from lower margin of eye to beyond posterior angle of lower jaw. Abdomen silvery, dotted with black pigment dots. Pectoral axil dotted black.

Distribution. Along Goa, Cochin, Quilon, Gulf of Mannar, Palk Bay, Chilka lake, Porto Novo and Godavary estuary. Among these places it is more abundant at Visakhapatnam and Kakinada. 


\section{Gazza Rüppel, 1835}

(Type species Gazza equulaeformis Rüppell, 1835

= Scomber minutus Bloch, 1797)

\section{Gazza minuta Bloch, 1797}

(Plate II, Fig. 7; Tables 1-3)

Scomber minutus Bloch, 1797, Systema Ichthylogiae, p. 110, tab. 429, fig. 2.

Material examined. 30 specimens of $83-123 \mathrm{~mm}$

Description. D.VIII, 15-16; P. ii, 13-14, i-ii; V. I, 5; A. III, 13-14; C. 15; 57-59.

As percent of standard length: Total length 129.89-134.72 (131.59); fork length 113.24-117.81 (115.20); predorsal 38.71-42.86 (40.32); preanal 49.25-54.95 (51.63); dorsal base 51.28-54.84 (53.22); anal base 39.08-44.44 (41.86); head 30.30-34.07 (31.87); dorsal height 15.15-20.83 (17.81); anal height 13.64-16.44 (15.05); pectoral 15.79-19.48 (17.55); depth 38.71-45.05 (42.00).

As percent of head length: Snout 23.81-29.17 (26.36); eye 33.33-40 (36.52); head height 84-100 (91.68).

Body oval, compressed and moderately deep. Dorsal and ventral profiles equally convex. Snout pointed. Mouth large, lips thick and broad. Mouth when protracted forms a horizontal tube. Gape of mouth oblique and near the middle of eye. Mandible at an angle of about $45^{\circ}$ with the horizontal. A single series of small sharp teeth on the upper jaw, with a big and curved canine tooth on each side of the symphysis. In the lower jaw a series of curved pointed teeth are present, becoming larger anteriorly, with a pair of symphysial canines, with a notch between them to receive the upper canines. Pre-operculum with an obtuse angle, its lower margin finely serrated. Two small spines on top of the head immediately above the eye and opposite its front margin. Lateral line convex from the origin and is parallel to the dorsal profile extending posteriorly, but getting obsolete near to the end of the soft dorsal fin. Ventrals with axillary scales. Tip of the ventrals not reaching the origin of anals. Caudal deeply forked. Ventrolateral lobes of light organs hypertrophied.

Color. Silvery, back grayish, upper half of the body with grayish, irregular marks, or vertical wavy lines or faint irregular blotches, extending to below lateral line. Membrane of spinous dorsal, black at the edge. Snout margin dotted black. Inner side of pectoral base with black dots. About seven grey irregular blotches along the lateral line. Front part of anal fin yellowish. Edge of the gill opening on the lower side, covered by the opercular flap also dotted black. A black narrow line along the base of the dorsal fin. Posterior edges of the caudal fin dusky. Black minute dots all over the ventral half of the body.

Distribution. Though it does not form a fishery by itself or dominate the catch at any particular locality, it contributes substantially to the silverbelly catch along both coasts of the country. It is distributed off Cochin, Cape Comorin, Quilon, Tuticorin, Pamban, Mandapam, Madras, Porto Novo, Visakhapatnam and Kakinada and especially abundant at Tuticorin, Pamban and Mandapam.

\section{Gazza achlamys Jordan and Starks , 1917}

(Plate II, Fig. 8; Tables 1-2)

Gazza achlamys Jordan \& Starks, 1917, Ann. Car. Mus., 11: 446, pl.45.

Material examined. 5 specimens of $82-110 \mathrm{~mm}$

Description. D.VIII, 16; P. ii, 13, ii; V. I, 5; A. III, 14; C. 15. Ll. 59-61.

As percent of standard length: Total length 129.55-134.18 (131.70); fork length 115.12-120.25 (117.09); predorsal 39.77-41.98 (40.64); preanal 50.62-52.33 (51.30); dorsal base 51.16-54.43 (52.33); anal base 39.77-44.30 (41.91); head 31.82-34.18; dorsal height 20.78; anal height 17.05-20.93 (19.18); pectoral 18.18-19.77 (18.73); depth 46.59-49.37 (47.71).

As percent of head length: Snout 24.00-28.57 (25.88); eye 35.71-39.29 (37.01); head height 95.59-100.00 (94.89). 
Body oval, somewhat compressed and deep. Dorsal and ventral profiles equally convex. The dorsal profile shows a slight concavity over the front border of the eye. Snout pointed. Mouth large, lips broad and thick. Mouth when protracted forms a horizontal tube. Gape of mouth oblique and opposite the middle of the eye. Mandibles almost straight, ascending with an angle of about $50-60^{\circ}$. A band of small villiform teeth on each side and a pair of symphysial canines on the upper jaw, lower jaw having a series of teeth on the sides, getting bigger when going forward, with a pair of large canine teeth at the symphysis, with a gap between them to receive the upper canines. Two small supraorbital spines present opposite the front border of eye. Pre-operculum with its lower margin finely serrated. Lateral line convex from the origin and runs parallel to the dorsal profile extending posteriorly up to the base of the caudal fin. Ventrals with axillary scales and tip of the ventrals do not reach the origin of the anals. Caudal deeply forked. Ventrolateral lobes of light organs hypertrophied.

Color. Body silvery, back grayish, with dark irregular marks or circles, extending to little beyond lateral line, which often disappear on preservation. Membrane of the spinous dorsal black in its distal portion. Snout tip dotted gray. Edge of soft dorsal also gray. Inner side of the pectoral fin dotted black and dark pigment spots present along the edge of the ventral half of the gill opening, covered by the opercular flap. Caudal dusky at its posterior margin. Minute black dots all over the ventral half of the body.

Distribution. Very rare in Indian waters with only stray specimens reported. It is reported from the Great Nicobar Island (Rani Singh and Talwar 1978b) and known to occur off southern India. It is reported from off Cochin for the first time in the present study.

\section{Acknowledgement}

The authors are very grateful to Dr. G. Syda Rao, Director, C.M.F.R.I. for encouragement and support. The authors also wish to express sincere thanks to Dr. Sathish Sahayak and Shri. N. Rudramurty for their help and support.

\section{Reference}

Abe, T. \& Haneda, Y. (1972) Descriptions of two new species of the ponyfish genus Leiognathidae from Indonesia. Scientific Report of Yokosuka City Musuem, 19,1-7.

Bloch, M.E. (1795) Naturgeschichte der auslandischen Fische, Berlin, 9, 397-432.

Chakrabarty, P. \& Sparks, J.S. (2007) Phylogeny and taxonomic revision of Nuchequula Whitley, 1932 (Teleostei: Leiognathidae), with the description of a new species. American Museum Novitates, 3588, 1-28.

Chakrabarty, P. \& Sparks, J.S. (2008) Diagnoses for Leiognathidae Lacepède, 1802, Equula Cuvier, 1815, Equulites Fowler 1904, Eubleekeria Fowler, 1904 and a new ponyfish genus (Teleostei:Leiognathridae). American Museum Novitates, 3623,1-11.

Chakrabarty, P., Amarasinghe, T. \& Sparks, J.S. (2008) Redescriptions of ponyfishes (Teleostei: Leiognathidae) of Sri Lanka and the status of Aurigequula Fowler, 1918. Ceylon Journal of Science (Biological Science), 37(2),143-161.

Chakrabarty, P., Chu, J., Luthfun, N. \& Sparks, J.S. (2010) Geometric morphometrics uncovers an undescribed ponyfish (Teleostei: Leiognathidae: Equulites) with a note on the taxonomic status of Equula berbis Valenciennes. Zootaxa, 2427, $15-24$.

Chakrabarty, P., Ho, H.C. \& Sparks, J.S. (2010) Taxonomic review of the ponyfishes (Perciformes: Leiognathidae) of Taiwan. Marine Biodiversity, 40, 107-121.

Cuvier, G. \& Valenciennes, A. (1828-1849) Histoire naturelle des Poissons, Paris-Strasbourg, 2-21 vol.11030 pp., 621 pls. (1$650)$.

Day, F. (1878) The fishes of India: being a natural history of fishes known to inhabit the seas and fresh waters of India, Burma and Ceylon, 419-420.

Forsskål, P. (1775) Descriptiones animalium avium, amphibiorum, piscium, insectorum, vermium; quae in itinere orientali observavit. Post mortem auctoris edidit Carsten Niebuhr. Hauniae. Description Animalium, p.1-164.

Fowler, H.W. (1918) New and little known fishes from the Phillipine Islands. Proceedings of Academy of Natural Sciences Philadelphia, 70, 2-71.

Günther, A. (1860) Catalogue of fishes in the British Museum, London, Vol. 2, 176-190.

Hamilton, F. (1822) An account of the fishes found in river Ganges and its branches i-viii, Edinberg, 39 pls., 405 pp.

Hubbs, C.L. \& Lagler, K.F. (1947) Fishes of great lakes region. Bulletin of Cranbrook Institute of Science, 26, 213 pp.

James, P.S.B.R. (1969) A new species of silverbelly Leiognathus jonesi (Family Leiognathidae: Pisces) from the Indian seas. Journal of Marine Biological Association of India, 11(1\&2) , 316-319. 
James, P.S.B.R. (1975) A systematic review of the fishes of the family Leiognathidae. Journal of Marine Biological Association of India, 17(1), 138-172.

James, P.S.B.R. (1984) Leiognathidae. FAO Species Identification Sheets for Fishery Purposes. Western Indian Ocean (Fishing area 51), FAO. (Ed. Fischer, W. and Bianchi, G.) Vol. II.

James, P.S.B.R. (2008) Osteo-taxonomic dinstinction of fishes of the family Leiognathidae. Indian Journal of Fisheries, 55 (4), 305-310.

James, P.S.B.R. \& Badrudeen, M. (1990) A new species of silverbelly Leiognathus striatus (Family: Leiognathidae: Pisces) from the Gulf of Mannar, India and redescription of Leiognathus fasciatus (Lacepede). Journal of Marine Biological Association of India, 32(1\&2), 217-226.

Jayabalan, N. \& Ramamoorthi, K. (1977 ) A reappraisal of the family Leiognathidae (Pisces). Matsya, 3, 87.

Jayabalan, N. (1985) A new species of silverbelly, Gazza shettyi (Pisces: Leiognathidae) from the Bay of Bengal. Matsya, 11, $42-45$.

Kimura, S., Ikejima, K. \& Iwatsuki, Y. (2008) Eubleekeria Fowler 1904, a valid genus of Leiognathidae (Perciformes). Ichthyological Research, 55, 202-203.

Kimura, S., Ito, Y., Peristiwady, T., Iwatsuki, Y., Yoshino, T. \& Dunlap, P.V. (2005) The Leiognathus splendens complex (Perciformes: Leiognathidae) with the description of a new species, Leiognathus kupanensis Kimura and Peristiwady. Ichthyological Research, 52, 275-291.

Kurup, B.M and Samuel, C.T. (1983) Systematics and distribution of fishes of the family Leiognathidae (Pisces) of the Vembanad Lake, Kerala (S. India). Records of Zoological Survey of India, 80(3\&4), 387-411.

Lacepède, B. (1798-1803) Histoire naturelle des Poissons, 5 vol., Paris I: 1798, 8+cxlvii+532 pp., 25 pls., 1 tabl (inset); II: 1800, 1xiv+632 pp., 20 pls.; III: 1801, 558 pp, 34 pls.; IV: 1802, xliv+728 pp., 16 pls.; V: 1803, xlviii+803 pp., 21 pls.

Lachner, E.A. \& Jenkins, R.E. (1971) Systematics, distribution and evolution of the Nocomis biguttatus species group (Family Cyprinidae: Pisces) with a description of a new species from the Ozark upland. Smithsonian Contributions to Zoology, 91, $28 \mathrm{pp}$.

Munro, I.S.R. (1955) The marine and freshwater fishes of Ceylon, Canberra, 349 pp.

Murty, V.S. ( 1978) Nemipterus mesoprion Bleeker (1953) (Nemipteridae - Pisces) a new record from the seas around India. Indian Journal of Fisheries, 25 (1\&2), 207-213.

Nelson, J. (1976) Fishes of the world. John Wiley and Sons, New York. 416 pp.

Rani, Singh \& Talwar, P.K. (1978a) Species of silver belly, Leiognathus indicus, (Pisces: Leiognathidae) from the Bay of Bengal. Bulletin of Zoological Survey of India., 1(3), 275-277.

Rani, Singh \& Talwar, P.K. (1978b) On the little known ponyfish, Gazza achlamys Jordan and Starks (Pisces: Leiognathidae) in the Indian waters. Current Science, 47(23), 932-931.

Shetty, H.P.C. (1963) A preliminary fishery survey of the Vembanad backwaters, Kerala. Survey Report of Central Inland Fisheries Research Insitutue, 2, 24 pp.

Snedecor, G.W. \& Cochran, W.G. (1967) Statistical Methods. Oxford and IBH Publishing Co., Culcutta-16, 593 pp.

Sparks, J.S. (2006) A new species of ponyfish (Teleostei: Leiognathidae: Photoplagios) from Madagascar, with a phylogeny for Photoplagios and comments on the status of Equula lineolata Valenciennes. American Museum Novitates, 3526,1-20.

Sparks, S.C. \& Lin, W-N. (1985) Study on the Leiognathid fishes of Taiwan. Bulletin of Institute of Zoology, Academia Sincia, $24,125-138$.

Sparks, J.S. \& Chakrabarty, P. (2007) A new species of ponyfish (Teleostei: Leiognathidae: Photoplagios) from the Philippines. Copeia, 2007 (3), 622-629.

Sparks, J.S., Dunlap, P.V. \& Smith, W.L.(2005) Evolution and diversification of a sexually dimorphic luminescent system in ponyfishes (Telesotei: Leiognathidae) including diagonosis of two genera. Cladistics, 21, 305-327.

Talwar, P.K. \& Kacker, R.K. (1984) Commercial sea fishes of India, Zoological Survey of India, 997 pp. 